preclude direct comparison. Walker and Brown (1964) retested the whole population of Ibstock $(5,406)$ for glycosuria five years after a similar screening test. They found that new clinical and "intermediate" diabetics as well as non-diabetic glycosuria had arisen in the previously tested population. Seven cases of symptomatic diabetes had been reported during follow-up.

\section{Survey Method}

The starting point of this study was general practice under the National Health Service in the United Kingdom. We believe that this has great advantages in population survey work for the following reasons. (1) The entire population can be studied regardless of occupation, age and infirmity, or financial consideration. (2) Practical details of testing can be planned to cause the least inconvenience to those who participate. (3) The relationship normally existing between doctor and patient encourages co-operation of individuals, which is the largest factor in achieving a high rate of follow-up. (4) The continuous morbidity from all cases and the mortality in the population are easily studied. (5) Close involvement of the hospital consultants with the participating family doctors ensures a definite policy in the management of those individuals discovered to have a diabetic or incidental abnormality. Advice and treatment can be administered firmly and consistently.

This work was made possible by Public Health Service Grant No. CD.00058, National Institutes of Health of America. Supplementary financial assistance was also received from the Lawson Tait Memorial Fund. We are grateful to Dr. R. Gaddie and his department for biochemical assistance. We are indebted to Mrs. J.
Harold, department of hospital statistics, Queen Elizabeth Hospital, Birmingham, and Mrs. J. Thompson, assistant to the regional statistician, Birmingham Regional Hospital Board. Invaluable assistance in tracing patients was given by National Health Service Executive Councils all over Britain and in particular by the Birmingham Executive Council. Mrs. R. Goodwin was the survey secretary and field worker.

REFERENCES

Butterfield, W. J. H. (1964). Proceedings of the Royal Society of Medicine, $57,196$.

Diabetes Survey Working Party (1962). British Medical fournal, 1, 1497.
Fajans, S. S. (1960). In Diabetes, ed. E. H. Williams, p. 398, New York, Hoeber.

FitzGerald, M. G., and Keen, H. (1964). British Medical Fournal, 1, 1568. Graham, G. (1950). Fournal of the Royal Institute of Public Health and Hygiene, 13, 227.

Hale-White, R., and Payne, W. W. (1926). Quarterly fournal of Medicine, $19,393$.

Hayward, R. E., and Lucena, B. C. (1965). Fournal of the Institute of Actuaries, 91, 286.

Hoffman, W. S. (1937). Fournal of Biological Chemistry, 120, 51

Keen, H. (1964). Proceedings of the Royal Society of Medicine, 57, 200.

Kosaka, K., Mizuno, Y., and Kuzuya, T. (1966). Diabetes, 15, 901.

Lawrence, R. D. (1947). Medical Clinics of North America, 31, 289.

McDonald, G. W., Fisher, G. F., and Burnham, C. (1965). Diabetes, 14, 473.

Marble, A. (1959). In Treatment of Diabetes Mellitus, ed E. P. Joslin H. F. Root, P. White, and A. Marble, 10th ed., p. 720. Philadelphia, Lea and Febiger.

Mosenthal, H. O., and Barry, E. (1950). Annals of Internal Medicine, 33, 1175. Robbers, H., and Rübelin, K. (1953). Deutsche medizinische Wochenschrift, 78, 1321

Sharp, C. L. (1964). Proceedings of the Royal Society of Medicine, 57, 193.

U.S. Public Health Service (1960). In Diabetes Program Guide, Washington, D.C., U.S. Government Printing Office.

Walker, J. B., and Brown, P. E. (1964). Lancet, 2, 246.

Wilkerson, H. L. C., and Krall, L. P. (1947). Fournal of the American

Medical Association, 135, 209.
Wilkerson, H. L. C., and Krall, L. P. (1953). Gournal of the American Medical Association, 152, 1322.

Zollinger, R. M., and Hoerr, S. O. (1947). Fournal of the American Medical Association, 134, 575 .

\title{
Resistant Urinary Infections Resulting from Changes in Resistance Pattern of Faecal Flora Induced by Sulphonamide and Hospital Environment*
}

\author{
KNUT LINCOLN, † M.D. ; GUNILLA LIDIN-JANSON, ‡ M.D. ; JAN WINBERG, $§$ M.D.
}

\author{
British Medical fournal, 1970, 3, 305-309
}

\begin{abstract}
Cummary: The faecal flora was studied in eight children $\checkmark$ admitted to hospital for treatment of a first urinary infection with sulphonamides. The original, sulphonamide-sensitive Escherichia coli organisms were found to disappear, to be replaced by other $E$. coli serotypes that were almost invariably resistant to sulphonamides. Some of these serotypes carried R-factors for multiple antibiotic resistance.

Possibly some urinary infections with antibioticresistant organisms may be due to faecal organisms whose resistance has been changed by previous antibiotic treatment. Hence it is important to study the effects of individual antibiotics on the faecal flora.
\end{abstract}

\section{Introduction}

Primary urinary tract infections are usually caused by sulphonamide-sensitive bacteria, while those recurring after treatment with sulphonamides are often caused by sulphon* Aided by Swedish Medical Research Council, Grant B68-19X-765-
04; Swedish Life Insurance Committee for Medical Research; the
Medical Society of Gothenburg; the Medical Faculty of the Uni-
versity of Gothenburg.
t Assistant, Department of Clinical Bacteriology, University of Gothen-
burg.
₹ Assistant, Department of Paediatrics, University of Gothenburg.
Assistant Professor, Department of Paediatrics, Crown Princess Lovisa's
Hospital, Stockholm. Hospital, Stockholm. amide-resistant ones. Re-evaluation of the figures from our earlier study (Bergström et al., 1968) show that the shorter the interval between treatment and recurrence the more frequently sulphonamide resistance occurs (Table I). Most of the

TABLE I.-Sulphonamide Resistance in Primary Infections and Recurrences Appearing Within a Year of Sulphonamide Therapy for 10 Days (151 Girls) or 60 Days (128 Girls)

\begin{tabular}{|c|c|c|c|}
\hline \multirow[t]{2}{*}{ Type of Infection } & \multirow[t]{2}{*}{$\begin{array}{l}\text { Days After } \\
\text { Start of } \\
\text { Therapy }\end{array}$} & \multicolumn{2}{|c|}{$\begin{array}{c}\text { Frequency of Sulphonamide- } \\
\text { resistant Infections Before and } \\
\text { After Treatment }\end{array}$} \\
\hline & & For 10 Days & For 60 Days \\
\hline $\begin{array}{l}\text { Primary infections } \\
\text { Recurrences }\end{array}$ & $\begin{array}{r}\text { Before } \\
1-13 \\
14-60 \\
61-365\end{array}$ & $\begin{array}{cc}15 / 151 & (10 \%) \\
5 / 5 & (100 \%) \\
12 / 24 & (50 \%) \\
7 / 23 & (30 \%)\end{array}$ & $\begin{array}{cc}13 / 128 & (10 \%) \\
7 / 7 & (100 \%) \\
14 / 15 & (93 \%) \\
8 / 19 & (42 \%)\end{array}$ \\
\hline
\end{tabular}

recurring infections recorded in that study were reinfections, not relapses (Bergström et al., 1967). Thus the appearance of resistant strains could not usually be ascribed to their development within the urinary tract. Since urinary bacteria commonly originate in the intestinal flora (Vahlne, 1945; Turck et al., 1962), treatment with sulphonamides may have caused a change in the resistance pattern of the intestinal flora, which then played a part in a subsequent urinary infection. The present study was undertaken to test this hypothesis.

Infants who had been admitted consecutively to hospital with non-obstructive, acute, febrile urinary tract infections 
had serial faecal cultures performed before, during, and after oral sulphonamide therapy. Changes in composition and antibiotic resistance pattern of the faecal flora, its correlation to the urinary flora at the onset and during recurrences, and the occurrence of $\mathbf{R}$-factors for multiple antibiotic resistance were studied. The rational basis for using increasingly powerful antibiotics to prevent recurrent urinary tract infections is questioned.

\section{Patients and Methods}

Study Group.-Eight infants with apparent primary nonobstructive urinary tract infections were admitted during the summer of 1967. None, with the exception of Case 1, who had had a five-day course of ampicillin at birth, had ever been given an antibiotic, according to the parents. Each infant was nursed in the same ward during a 10-day course of sulphonamides and was readmitted for follow-up at 30,60, and 90 days after therapy had been started, and in case of recurrence. Altogether 104 faecal specimens were obtained from these patients.

Controls.-Twenty-four infants who had been admitted to hospital for various reasons three to six months later, but nursed in the same ward as the study group, were compared as controls. These infants were included to investigate the persistence of $R$-factors in the ward, to study the effect on the faecal flora of admission to hospital without antibiotic therapy being given, and to compare faecal and urethral flora. Thirty-four faecal and 33 urethral samples were taken from 24 patients.

Treatment and Prophylaxis.-Sulphafurazole (Gantrisin) $200 \mathrm{mg} . / \mathrm{kg} . / 24$ hours in four doses a day for 10 days was given as a therapeutic dose, and $50 \mathrm{mg} . / \mathrm{kg} . / 24$ hours in two doses a day as a prophylactic dose. Therapy was discontinued about 60 hours before urinary cultures were performed.

Specimen Collection.-Faecal and urethral specimens were taken as rectal and periurethral swabs, which were then transported to the laboratory in tubes with a modified Stewart medium (Möller, 1966). Specimens of urine were collected after thorough cleansing and transported to the laboratory in ice (Lincoln and Winberg, 1964).

\section{Culture and Other Bacteriological Tests}

The rectal and urethral swabs were streaked on three Drigalski (lactose bromthymol blue) agar plates (Kauffmann, 1966), on one azide-sorbitol bromthymol blue agar plate (Kjellander, 1960), and on one plain blood agar plate. Specimens of urine were cultured with a calibrated loop technique on the same substrates. All plates were free of sulphonamides or other antibiotics, were incubated aerobically, and were read twice, after about 20 and 44 hours.

Ten colonies of Escherichia coli or coliforms from each faecal and urethral specimen were subcultured. Urine plates usually showed only one colony type and were then regarded as pure cultures (Vosti et al., 1964). The isolates from faeces, urethra, and urine were submitted to simplified $E$. coli $O$ grouping and to tests for urease, indole production, and antibiotic sensitivity. The $\mathrm{O}$-grouping was performed in Perspex plates with 80 spherical cavities $16 \mathrm{~mm}$. in diameter, using $0.05 \mathrm{ml}$. of overnight broth culture, heated to $100^{\circ} \mathrm{C}$. for one hour, and $0.05 \mathrm{ml}$. of immune serum dilution, making an average final serum dilution of $1 / 1,000$ in the $0 \cdot 1-\mathrm{ml}$. reaction volume. The direct bacterial agglutination was read after about 18 hours at $50^{\circ} \mathrm{C}$. with a Zeiss-Stereo II microscope at 10 to 16 times magnification (Lincoln, 1966). Antisera to $11 \mathrm{E}$. coli $O$ groups-1, 2, 3, 4, 6, 7, 8, 9, 18, 25, and 75-were used. Twenty-six non-groupable $E$. coli strains were investigated by Drs. I. and F. $\phi$ rskov, Copenhagen. Antibiotic sensitivity was tested with a single disc diffusion method (Ericsson et al.,
1954). The following drugs were used: sulphasomidine, penicillin G, tetracycline, chloramphenicol, streptomycin, ampicillin, nitrofurantoin, and nalidixic acid. Determinations of sulphonamide' concentrations in faeces and urine were carried out by a microbiological method, using a sensitive Staphylococcus albus strain. The measured antibacterial effect could be eliminated by para-aminobenzoic acid.

\section{Transfer of Resistance}

Five resistant donor strains were selected because they did not ferment lactose, and three sensitive lactose-fermenting recipient strains were used. One strain (06) was isolated from the faeces of a patient, and the other two ("K12" and O100) were supplied by Drs. I. and F. $\phi$ rskov, Copenhagen.

\section{Resuits}

\section{Influence of Chemotherapy on Faecal Flora}

In Case 2 the primary urinary tract infection was caused by sulphonamide-sensitive $E$. coli $\mathrm{O2}$, which was also the predominant strain in the faecal sample (Fig. 1). About 48 hours

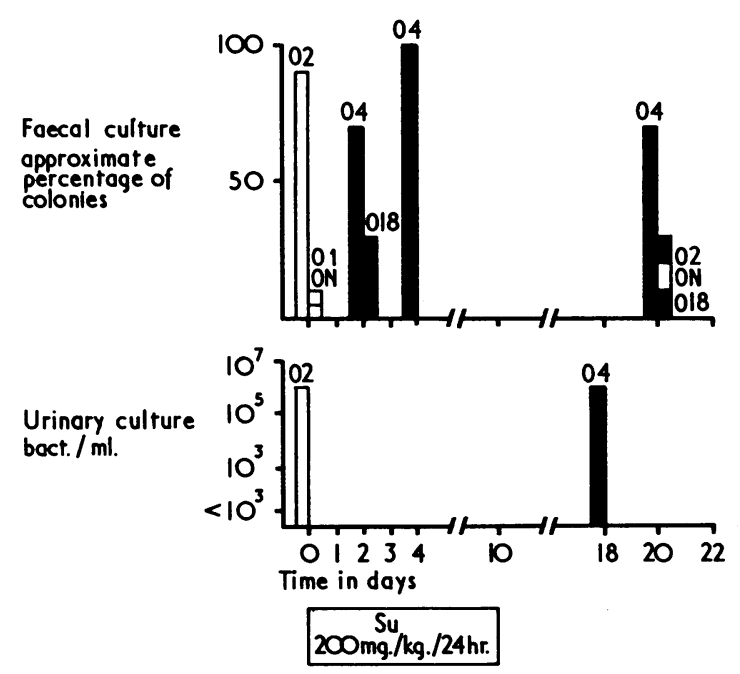

FIG. 1.-Composition and sulphonamide sensitivity of faecal and urinary florae in relation to treatment in Case 2, a 3-month-old boy, with acute first-time pyelonephritis and one reinfection. Open columns= sensitive to sulphonamide. Solid columns=resistant to sulphonamide.

after therapy was started this strain was replaced in the faeces by sulphonamide-resistant $E$. coli 04 and 018 . At day 18 the boy was readmitted with fever, when urinary culture showed reinfection with resistant $E$. coli 04 . This case illustrates the qualitative changes in the Gram-negative faecal flora induced by sulphonamide therapy and how this may determine the bacterial species and resistance of a recurrence. The occurrence of resistant reinfections and the changes in sulphonamide sensitivity of the faecal flora in five infants are shown in Fig. 2. In two patients (Cases 1 and 2) resistant strains still predominated in the faecal flora three to four months after sulphonamide therapy was discontinued.

The faecal findings for the entire study group during the first fortnight after onset of therapy are summarized in Fig. 3. The proportion of sulphonamide-resistant $E$. coli isolates rose from 12 to $98 \%$ during therapy and declined to $71 \%$ immediately after. Sulphonamide therapy also greatly increased the proportion of enterococci in the faeces. Three patients had 


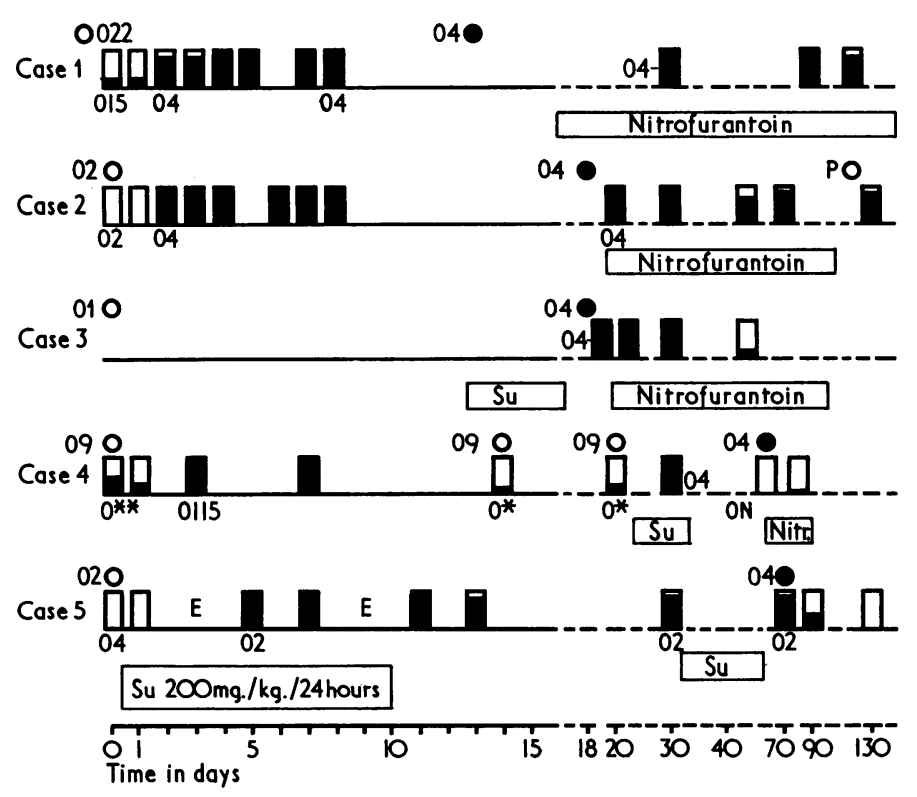

FIG. 2.- Composition and sulphonamide sensitivity of faecal and urinary florae in relation to treatment in the five patients who had a resistant recurrence. Only the predominant faecal strain is indicated by $O$ group. Sulphonamides induced a rapid change of both the predominant $O$ group and the sensitivity pattern of the faecal $E$. coli strains. $O^{\star}=N e g$. $01-$ $0149-E$. coli not belonging to any of the 1490 antigen groups so far known. $\mathrm{O}^{\star \star}=\mathrm{O} 5, \mathrm{O} 71(50 \%)$, and $0115(50 \%)$. Open columns $=$ specimens of faeces sensitive to sulphonamide. Solid columns=specimens of faeces resistant to sulphonamide. Open and solid circles=specimens of urine during urinary tract infection. $\mathbf{E}=$ Pure culture of enterococci.

equal sulphonamide concentrations in both faeces and urine (Table II); this probably explains the demonstrated effect on the faecal flora.

\section{Analysis of Resistance Patterns}

Several patterns of multiple resistance were observed in the faeces after sulphonamide therapy (Table III). The SuC and
TABLE II.-Sulphonamide Concentration of Simultaneous Samples of Faeces and Urine of Three Female Infants on Oral Sulphafurazole Therapy

\begin{tabular}{c|c|c|c}
\hline \multirow{2}{*}{ Age in Months } & $\begin{array}{c}\text { Day After Start } \\
\text { of Therapy }\end{array}$ & \multicolumn{2}{|c}{$\begin{array}{c}\text { Sulphonamide concentration } \\
\text { (mg./100 ml.) }\end{array}$} \\
\cline { 2 - 4 } & & Of Faeces & Of Urine \\
\hline 7 & 7 & 140 & 110 \\
9 & 2 & 120 & 80 \\
10 & 3 & 320 & 300 \\
\hline
\end{tabular}

SuCA patterns are of special interest, since they appeared in an $E$. coli $\mathrm{O} 4$ which caused reinfection in five patients (Fig. 2; Table III). The influence of environment alone and of environment plus sulphonamide therapy on the appearance of multiple-resistant $E$. coli in the faecal flora is shown in Table IV. The stay in the ward alone caused a colonization of the intestine by the multiple-resistant ward flora. In patients not receiving sulphonamides there was a coexistence between sensitive host flora and multiple-resistant ward

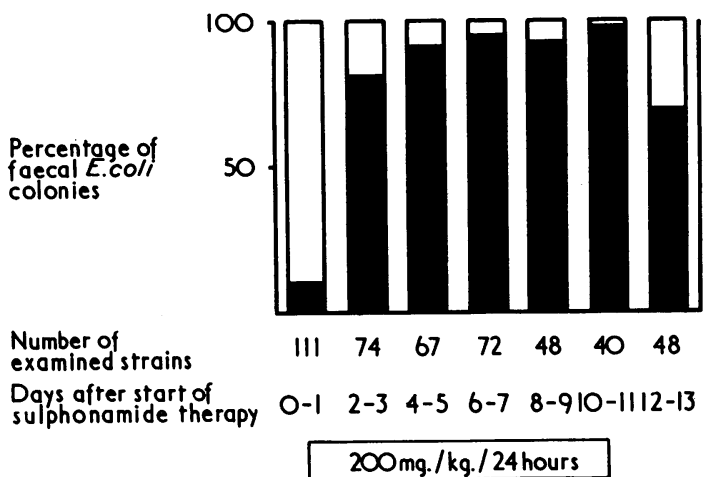

FIG. 3.-Frequency of sulphonamide-sensitive and sulphonamideresistant faecal $E$. coli colonies cultured before, during, and shortly after a 10-day course of sulphonamide. 461 colonies isolated from 51 rectal swab cultures from seven patients belonging to the study group. Open swab cultures from seven patients belonging to the study group. Open
columns = sensitive to sulphonamide. Solid columns=resistant to sulphonamide.

TABLE III.-Resistance Patterns of Faecal and Infecting Urinary Bacterial Strains Before, During and After a 10-day Course of Sulphafurazole

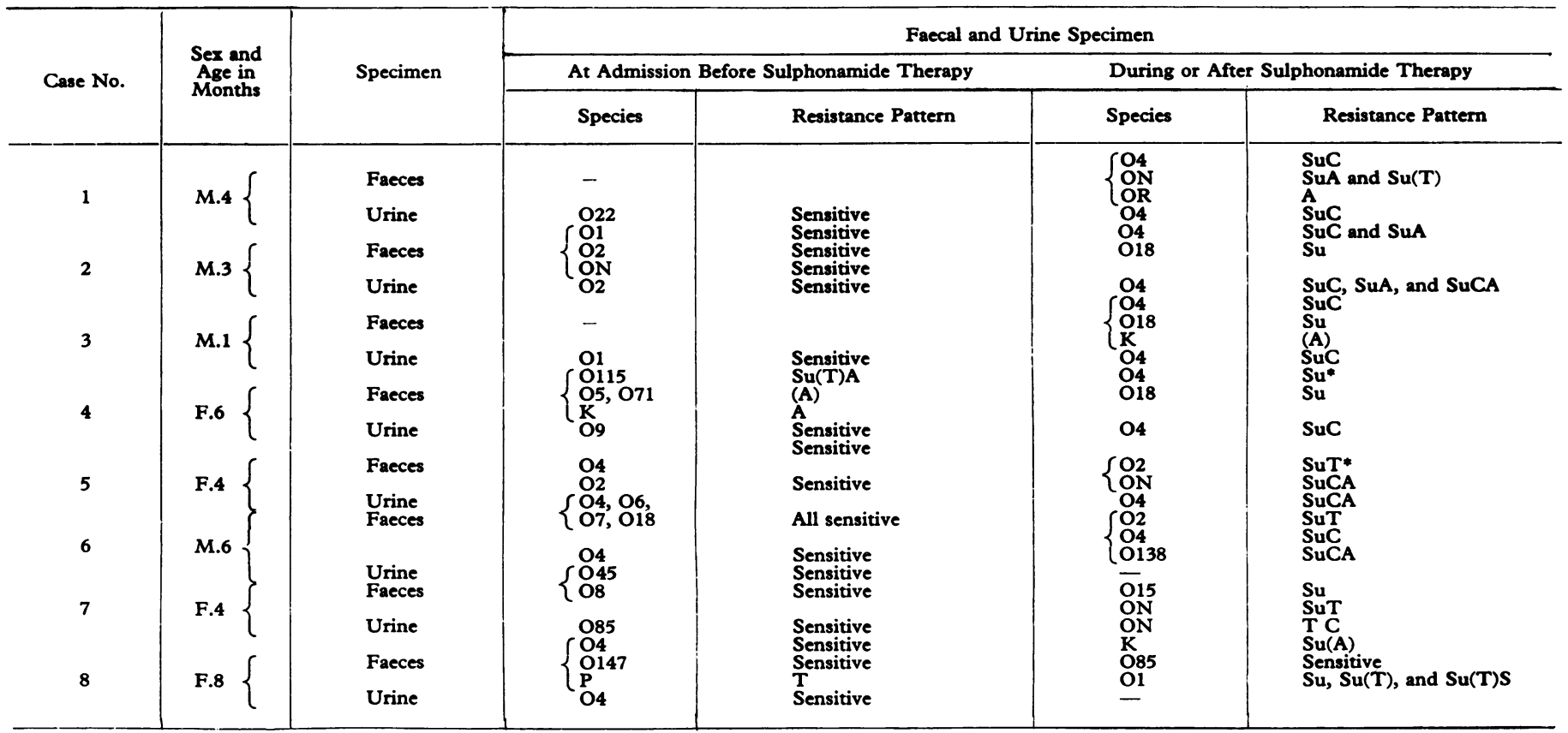

Each period is represented by one single iaecal specimen from which 10 colonies were investigated (see also Fig. 2.).

- Two courses of sulphafurazole given.

Abbreviations and definitions:

O1 $=$ E.coli of $\mathrm{O}$ antigen group 1.

ON-E.coli not groupable with Ó antisera $1,2,3,4,6,7,8,9,18,25,75$

$\mathrm{OR}=E$.coli in a rough phase. $O$-grouping not possible because of spontaneous agglutination.

$\mathrm{E}=$ Enterococci. $\mathrm{K}=\mathrm{Klebsiella-Enterobacter.} \mathrm{P}=$ Proteus.
In the resistance patterns, Su means resistance to sulphonamide, $\mathrm{T}$ to tetracycline, $\mathrm{C}$ to chloramphenicol, $\mathrm{S}$ to streptomycin, A to ampicillin. Parentheses denote partial resistance. 
flora. On the other hand, the flora of those patients receiving sulphonamides rapidly became dominated by resistant bacteria, most of which were multiple-resistant.

\section{In-vitro Transfer of Resistance}

A few experiments were made to transfer resistance from $E$. coli strains isolated from the patients to sensitive $E$. coli strains. Different patterns of resistance, including simple sulphonamide resistance, were transferred in vitro (Table V).

TABLE V.-Transfer of Resistance Between E. coli Strains

\begin{tabular}{c|c|c|c|c|c}
\hline \multicolumn{3}{c|}{ Donor strains } & \multicolumn{3}{c}{ Recipient strains } \\
\hline Strain & O group & $\begin{array}{c}\text { Resistance } \\
\text { Pattern }\end{array}$ & Strain & O group & $\begin{array}{c}\text { Resistance Pattern } \\
\text { After Transfer }\end{array}$ \\
\hline 1 & O4 & SuCA & 6 & O6 & SuCA \\
2 & O75 & SuCA & 6 & O6 & SuCA \\
3 & ON & SuCA & 6 & O6 & SuCA \\
4 & O4 & SuA & 6 & O6 & Su \\
4 & O4 & SuA & 7 & Su \\
4 & O4 & SuA & 8 & O100 & SuA \\
4 & O4 & SuA & 8 & O100 & Su \\
4 & O4 & SuA & 8 & O100 & O6 \\
5 & O75 & SuC & 7 & O6 & No transfer obtained \\
5 & O75 & SuC & 7 & O100 & SuC \\
\hline
\end{tabular}

Strains 1-6 were isolated from patients, strain 7 is Lederberg's strain W3132 (E. coli $\mathrm{K} 12)$, and strain 8 is Orskov's strain D512. Strains 6, 7, and 8 were before transfer sensitive to all common antibiotics.

After about a year of storing as deep agar stab cultures under paraffin oil, resistance to one or more drugs was sometimes lost.

\section{Correlation of Faecal, Urinary, and Urethral Flora}

In the study group, urinary $E$. coli $O$ group was found in the faeces of five out of six patients before treatment had been given (Fig. 2; Table III). In only one patient (Case 2) did this strain predominate. Five patients were reinfected by multiple-resistant $E$. coli $\mathrm{O} 4$, and in four of these this strain was found in their faeces (Figs. 1 and 2; Table II). Thus it appears that the faecal changes preceded reinfection and determined the bacteriology of the recurrence. The multipleresistant $E$. coli $\mathrm{O} 4$ strain may have had a certain affinity for the urethra. In Case 3 serial samples showed that this strain remained in the urethra for at least eight months, though it was not found in the two faecal samples taken during this period. In Cases 1 and 2, however, the $E$. coli $\mathrm{O} 4$ strain remained in the faeces for at least four months. The urethral colonization was not investigated in these patients. A comparison of the faecal and urethral flora in paired specimens from the control group showed a correlation in 25 out of 29 . Serial sampling in two of the four pairs in which there was no correlation showed that the urethral strain had earlier dominated the faecal flora. Such events may explain occasional differences between faecal flora and urinary bacteria.

\section{Epidemiology}

The above observations were made during June and July 1967 and suggested that SuC and SuCA resistance patterns, especially those connected with $E$. coli $\mathrm{O} 4$, were common in the ward flora. A further survey was carried out in November and December 1967 in which 34 faecal and 33 urethral samples were taken from 24 patients. During this time the SuC or SuCA patterns of faecal, urethral, or urinary $E$. coli were still found in almost all patients who had stayed in the ward for some days, with or without antibiotic therapy. In some instances tetracycline resistance was added to form a SuTCA resistance pattern (Table IV). Some patients already had the SuC or SuCA pattern on admission, since they had all been cared for in the ward earlier during the year. Whereas in June and July most of the multiple-drug-resistant strains were $E$. coli $\mathrm{O} 4$, in November they were $E$. coli $\mathrm{O}$, which may indicate a transfer of $\mathbf{R}$-factors to the prevailing hospital strains. This SuCA-resistant O9, like the 04 strain, also seemed to be an effective colonizer.

\section{Discussion}

In the early 1940s poorly absorbed sulphonamide compounds were shown to affect the intestinal flora of animals and humans (Marshall et al., 1940; Poth and Knotts, 1941; Kirby and Rantz, 1942; Gant et al., 1943). The present study shows that a so-called well-absorbed sulphonamide compound may appear in high concentrations in the bowel, thus encouraging a nosocomial colonization of the gut by multipleresistant bacteria leading to reinfection of the urinary tract by resistant organisms. Preliminary observations suggest that considerably smaller doses of sulphonamides than those used in this investigation may exert a similar effect. The current use of very potent new antibiotics to prevent resistant infections may also cause profound changes in the intestinal flora and in time produce more complicated resistance patterns in bacteria causing reinfections. Thus, according to our results, the suggestion by Schwartz et al. (1969) that the gut flora could be changed by administering non-absorbed antibiotics and thereby prevent recurrences would have the reverse effect.

If the problem of resistant urinary tract infections is seen in the light of the influence of therapy on intestinal flora, a drug which combines a good antibacterial effect in the urinary tract with little or no effect on the intestinal flora seems to offer the best protection against reinfection. Preliminary observations suggest that nitrofurantoin may be one such drug. On the other hand, nitrofurantoin may encourage colonization of the urethra or genital tract with Proteus and possibly Pseudomonas. Thus it is important that different antibiotics, especially urinary antiseptics, are evaluated systematically with regard to their effect on the intestinal and urethral flora. Similarly, treatment at home and in hospital should be evaluated with regard to possible differences in the effect on the faecal flora.

TABLE IV.-Occurrence of Antibiotic-resistant Faecal E. coli in Three Groups of Patients

\begin{tabular}{|c|c|c|c|c|c|c|c|c|}
\hline \multirow[b]{2}{*}{ Group } & \multirow[b]{2}{*}{ Category of Patients } & \multirow{2}{*}{$\begin{array}{c}\text { No. of } \\
\text { Patients }\end{array}$} & \multirow{2}{*}{$\begin{array}{c}\text { No. of } \\
\text { Faecal } \\
\text { Samples }\end{array}$} & \multicolumn{4}{|c|}{$\begin{array}{l}\text { No. of Different Strains Distinguished by Host, } \\
\text { O group, and Resistance }\end{array}$} & \multirow[b]{2}{*}{ Observed Combinations of Resistance } \\
\hline & & & & $\begin{array}{l}\text { Sensitive } \\
\text { to common } \\
\text { Antibiotics }\end{array}$ & $\begin{array}{l}\text { Resistant to } \\
\text { Sulphona- } \\
\text { mide Only }\end{array}$ & $\begin{array}{l}\text { Multiply } \\
\text { Resistant }\end{array}$ & $\begin{array}{c}\text { Ratio } \\
\text { Sensitive } \\
\text { to Multiple } \\
\text { Resistant } \\
\text { Strains }\end{array}$ & \\
\hline \multirow[t]{2}{*}{$\begin{array}{l}1 \\
2 \\
3\end{array}$} & \multirow{2}{*}{$\begin{array}{l}\text { Just admitted to ward (no antibiotics } \\
\text { given) } \\
\text { Sttaying in ward (no antibiotics given) } \\
\text { Receiving Sulphonamide Therapy for } \\
\text { at least } 3 \text { days }\end{array}$} & $\begin{array}{l}6 \\
5\end{array}$ & $\begin{array}{l}6 \\
9\end{array}$ & $\begin{array}{r}13 \\
8\end{array}$ & $\begin{array}{l}0 \\
1\end{array}$ & $\begin{array}{l}1 \\
9\end{array}$ & $\begin{array}{r}13 / 1 \\
8 / 9\end{array}$ & $\begin{array}{l}\text { Su(T)A } \\
\text { SuA; SuC; SuT; Su(S); SuCA }\end{array}$ \\
\hline & & 10 & 11 & 0 & 5 & 17 & $0 / 17$ & 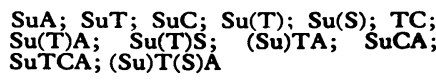 \\
\hline
\end{tabular}


A correlation between urinary and faecal bacteria has been shown (Vahlne, 1945; Turck et al., 1962; Vosti et al., 1964; Andersen et al., 1965; Grüneberg et al., 1968). In the present investigation $\mathrm{O}$ groups and resistance patterns of urinary bacteria in recurrent infections have closely reflected preceding changes in the intestinal flora. The discrepancy between urinary and faecal flora was explained by serial cultures from faeces and urethra which showed how an acquired resistant strain disappeared from the faeces but persisted in the urethra. Should a recurrence occur in such patients the bacteriology will probably be determined by the prevalent urethral flora, as is suggested by Cox et al. (1968). The influence of sulphonamide treatment on the intestinal flora may explain the high frequency of sulphonamide resistance in early reinfections and the lower frequency in late reinfections, as well as the failure of long-term administration of sulphonamides to prevent reinfection (Bergström et al., 1968; KincaidSmith and Fairley, 1969). In an earlier study (Bergström et al., 1967) of girls with up to eight consecutive infections caused by different strains we raised the question whether this was due to a change in the intestinal flora, from which the bacteria probably came, or to an acquired immunity to strains which had infected the patients earlier. The present study, however, shows that these observations may be explained by a change in the intestinal flora as a result of therapy. Nevertheless, the role of immunity is still open to question.

The increasing frequency of bacteria which carry $R$ factors and convey resistance to several antibiotics (Smith and Armour, 1966; Aandahl, 1968; Lewis, 1968) is a threat to successful antibiotic treatment of gastrointestinal and urinary infections. The administration of one drug by itself may lead to a selection of bacteria with episomal multiple drug resistance. The finding that episomes control bacterial virulence factors which are transmittable at the same conjugation with R-factors suggests a new possible mechanism for the selection of virulent bacterial strains in hospitals (Smith and Halls, 1967, 1968). Furthermore, bacteria with drug resistance of this type seem to be more viable and competent for reproduction than resistant mutants (Watanabe, 1963; Meynell et al., 1968). The efficiency with which the multiple-resistant bacteria colonized the gut and the urethra may indicate such properties which may seriously affect the management of urinary tract infections.

In the epidemiological survey carried out six months after the care of the study group patients, multiple resistant strains remained in the ward, though the main bacterial carrier by that time was no longer $E$. coli 04 , but $E$. coli 09 . Bacteria with episome-mediated resistance are common in patients with urinary tract infections (Smith and Armour, 1966; Aandahl, 1968) and the present study shows how rapidly such strains may be acquired during antibiotic therapy in a hospital environment. One question raised by this investigation is therefore whether, as a primary aim in handling urinary tract infections, the faecal flora should not be kept sensitive to the commonly used antibiotics. Limiting, as much as possible, the care in hospital of patients in need of antibiotic treatment for urinary tract infection might be one answer until agents which do not influence the faecal flora are found.

The skilful technical assistance of Mrs. Ruth Bergesen, Mrs. Brita Drews, and Mrs. Siv Mangél is appreciated. We are indebted to Drs. Ida and Frits Orskov at the W.H.O. International Escherichia Centre, Statens Seruminstitut, Copenhagen, for help with serological classification of some of the more uncommon $E$. coli strains and supply of $E$. coli strains from their type collection.

\section{REFERENCES}

Aandahl, E. H. (1968). Acta Pathologica et Microbiologica Scandinavica, 74, 26.

Andersen, H. J. Lincoln, K., Ørskov, F., Ørskov, I., and Winberg, J. (1965). Fournal of Pediatrics, 67, 1073.

Bergström, T., Lincoln, K., Ørskov, F., Ørskov, I., and Winberg, J. (1967). Fournal of Pediatrics, 71, 13.

Bergström, T., Lincoln, K., Redin, B., and Winberg, J. (1968). Acta Paediatrica Scandinavica, 57, 186.

Cox, C. E., Lacy, S. S., and Hinman, F. (1968). fournal of Urology, 99, 632.

Ericsson, H., Högman, C., and Wickman, K. (1954). Scandinavian fournal of Clinical and Laboratory Investigation, Suppl. No. 11, p. 21.

Gant, O. K., Ransone, B., McCoy, E., and Elvehjem, C. A. (1943). Proceedings of the Society for Experimental Biology and Medicine, 52, 276.

Grüneberg, R. N., Leigh, D. A., and Brumfitt, W. (1968). In Urinary Tract Infection, edited by F. O'Grady and W. Brumfitt, p. 68.

London, Oxford University Press.
Kaufmann, F. (1966). The Bacteriology of Enterobacteriaceae. Copenhagen, Munksgaard.

Kincaid-Smith, P., and Fairley, K. F. (1969). British Medical fournal,

Kirby, W. M. M., and Rantz, L. A. (1942). Fournal of the American Medical Association, 119, 615

Kjellander, J. (1960). Acta Pathologica et Microbiologica Scandinavica, 49, Suppl. No. 136.

Lewis, M. J. (1968). Lancet, 1, 1389.

Lincoln, K. (1966). In III International Congress of Nephrology, Abstracts. p. 232 .

Lincoln, K., and Winberg, J. (1964). Acta Paediatrica Scandinavica, 53, 307.

Marshall, E. K., jun., Bratton, A. C., White, H. J., and Litchfield, J. T., jun. (1940). Bulletin of the Fohns Hopkins Hospital, 67, 163.

Meynell, E., Meynell, G. G., and Datta, N. (1968). Bacteriological Reviews, 32, 55.

Möller, A. (1966). Microbiological Examination of Root Canals and Periapical Tissues of Human Teeth, p. 365. Gothenburg, Akademiförlaget.

Poth, E. J., and Knotts, F. L. (1941). Proceedings of the Society for Experimental Biology and Medicine, 48, 129.

Schwartz, H., Schirmer, H. K. A., Ehlers, B., and Post, B. (1969). fournal of Urology, 101, 765 .

Smith, D. H., and Armour, S. E. (1966). Lancet, 2, 15.

Smith, H. W., and Halls, S. (1967). Fournal of General Microbiology, 47,

Smith, H. W., and Halls, S. (1968). Foumal of General Microbiology, 52,

Turck, M., Petersdorf, R. G., and Fournier, M. R. (1962). Fournal of Clinical Investigation, 41, 1760.

Vahlne, G. (1945). Acta Pathologica et Microbiologica Scandinavica,

Suppl. No. 62, p. 1.
Vosti, K. L., Gooldberg, L. M., Monto, A. S., and Rantz, L. A. (1964). fournal of Clinical Investigation, 43, 2377.

Watanabe, T. (1963). Bacteriological Reviews, 27, 87. 